\title{
MANAJEMEN PENINGKATAN KINERJA GURU BERBASIS MBS
}

\author{
Risbon Sianturi \\ Universitas Pendidikan Indonesia (UPI) Tasikmalaya \\ Tasikmalaya, Jawa Barat, Indonesia \\ risbonsianturi@gmail.com
}

\begin{abstract}
ABSTRAK
Kinerja seorang guru pada dasarnya dapat meningkat dan menurun serta sangat bergantung pada proses manajemen peningkatan kinerja itu sendiri. Berkenaan dengan fungsi pengendalian kinerja guru yang menjadi tanggung jawab kepala sekolah dan pengawas ini, pada faktanya masih banyak ditemukan distorsi. Fenomena tersebut sering ditemukan dalam proses pembinaan kinerja guru, khususnya di SMPN 1 Lembang, SMPN 1 Padalarang, dan SMPN 1 Cililin. Oleh karenanya, dipandang perlu adanya suatu pengkajian yang lebih mendalam berkaitan dengan manajemen peningkatan kompetensi profesional dan kinerjanya guru di ketiga SMP negeri tersebut. Paradigma penelitian yang digunakan untuk mengkaji hal ini adalah dengan menerapkan metode naturalistic inquiry serta pendekatan model Deming (PDCA), dengan subjek penelitiannya ditentukan secara purposive. Hasil penelitian ini menunjukkan bahwa dalam program peningakatan kinerja guru di ketiga sekolah tersebut pada umumnya dilakukan melalui kegiatan-kegiatan pembinaan di luar sekolah, sementra di lingkungan sekolah lebih sering dilakukan dalam bentuk supervisi dan kegiatan sharing dalam MGMP. Dalam perencanaannya pun tidak dilakukan perumusan prosedur dan kriteria assessment dari kegiatan-kegiatan tersebut. Pengorganisasiannya diselaraskan dengan visi dan tujuan sekolah serta ditunjang oleh upaya memfasilitasi mentor. Namun, pada proses pelaksanaan dan pengawasannya, kegiatan-kegiatan peningkatan kinerja guru ini tidak dikembangkan dalam program tersendiri sebagai suatu program peningkatan kinerja guru, sehingga setiap kegiatannya terkesan insidental dan tidak berkesinambungan dari tahun ke tahun. Oleh karenanya dalam penyelenggaraan manajemen peningkatan kinerja guru di ketiga SMP Negeri tersebut perlu dikelola secermat mungkin dengan mengoptimalkan seluruh fungsi manajemen, dan senantiasa selalu mengkaji dan mempertimbangkan berbagai tuntutan kebutuhan profesional guru.
\end{abstract}

Kata Kunci: manajemen, peningkatan kinerja, kinerja guru

\section{ABSTRACT}

Performance of a teacher increases and decreases as well as highly dependent on the process of the increasing the performance management itself. With regard to control function of teacher performance that should be the responsibility of the school principal and the superintendent, in in fact, there are still many distortion. Those phenomenon often found in the process of teacher performance guidance, especially at SMPN 1 Lembang, SMPN 1 Padalarang, and SMPN 1 Cililin. Thus, deemed a deeper assessment of teacher performance management necessarily to improve professional competency and its performance in the three junior high schools. This paradigm research that is used to assess applies the naturalistic inquiry methods and deming model approach, and the subject of this research were selected purposively. The result indicates that in the increasing performance of teachers at those three Junior High Schools, iIn general, it done through activities guidance outside the school, meanwhile, in the school more often is in the form of supervision and sharing activities in MGMP. Also in planning was not done the formulation of procedure and the criteria for assessment of the activities. The organizing that applied is aligned with vision and the purpose of each schools, and it is supported by attempts to serve the mentors. But, on implementation process and supervision, this improvement teacher performance activities are not to be developed in specific form, so it's look like the incidental activities and so not to be continuing. Thus, the inscreasing of teacher performance management at those schools need to be perfectly managed with optimizing all of management functions, and need to considering all of teacher's need.

Keywords: management, increasing of performance, teacher performance. 


\section{Kebijakan: Jurnal Ilmu Administrasi Volume 12, Nomor 1, Januari 2021 \\ E-ISSN: 2656-2820 \\ P-ISSN 1829-5762}

\section{PENDAHULUAN}

Pendidikan tidak terlepas dari suatu proses belajar setiap individu yang terlibat di dalamnya. Dalam hal ini, istilah belajar dapat didefinisikan dalam arti luas maupun dalam arti sempit. Suatu proses belajar dapat terjadi apabila seseorang yang menjalani proses belajar itu menunjukkan tingkah laku yang berbeda dari sebelumnya, dengan kata lain, belajar menempatkan seseorang dari status abilitas yang satu ke tingkat abilitas yang lain. Di sinilah sekolah berperan sebagai organisasi pembinaan dan pengembangan kualitas sumberdaya manusia yang dikemas dalam bentuk sistem pendidikan. Berkaitan dengan proses penyelenggaraan organisasi sekolah, guru sebagai salah satu komponen terpenting dari organisasi sekolah senantiasa menjadi sorotan perhatian. Segala bentuk keberhasilan organisasi sekolah, terutama yang berkaitan dengan output dan outcome pembelajaran siswa, selalu dikaitkan dengan kinerja guru di sekolah yang bersangkutan. Oleh karenanya, upaya peningkatan kinerja guru ini terus dilakukan, yang bukan hanya dalam bentuk pelibatan guru pada program-program pengembangan, tetapi juga melalui pengelolaan, pengawasan, dan pengendalian kinerja oleh kepala sekolah. Demikian pula halnya dengan upaya peningkatan kinerja guru di SMPN 1 Lembang, SMPN 1 Padalarang, dan SMPN 1 Cililin Kabupaten Bandung Barat.

Hal yang menjadi persoalan terkait dengan upaya peningkatan kinerja guru di ketiga SMP tersebut adalah: (1) masih terkesan adanya suatu fenomena belum optimalnya kinerja guru yang tampak pada komponen prestasi kerja, tanggung jawab, ketaatan, kejujuran kerjasama, dan prakarsa; (2) penilaian sasaran kinerja guru masih ditemukan ketidaksesuaian perhitungan sebagai akibat dari kesalahan-kesalahan teknis yang luput dari pengawasan dan pemeriksaan, yang pada akhirnya hal tersebut dapat mempengaruhi ketidak-akuratan dalam pengukuran kinerja guru itu sendiri; serta (3) tindakan supervisi yang dilakukan secara berkelanjutan dengan mengukur setiap komponen kompetensi yang perlu dipenuhi setiap guru oleh kepala sekolah dan pengawas sekolah belum cukup untuk memotivasi kinerja guru, karena di samping penilaian yang dilakukan lebih bersifat formalitas dan kurang objektif, komunikasi dan layanan pembinaan dalam pemecahan masalah kinerja yang dihadapi guru pun masih belum optimal, serta pengawasan yang terkesan tidak terarah pada penemuan atau pemberian solusi.

\section{Rumusan Masalah}

Berdasarkan pada fakta dan fenomena yang terjadi berkaitan dengan kinerja guru pada SMPSMP Negeri di Kabupaten Bandung Barat sebagaimana diuraikan sebelumnya, penelitian ini difokuskan pada manajemen peningkatan kualitas kinerja guru pada SMP Negeri di Kabupaten Bandung Barat, dengan masalah yang dirumuskan mencakup:

1. Bagaimana perencanaan peningkatan kinerja guru yang dilaksanakan pada SMP Negeri di Kabupaten Bandung Barat?

2. Bagaimana proses pelaksanaan peningkatan kinerja guru pada SMP Negeri di Kabupaten Bandung Barat?

3. Bagaimana proses pengawasan dan evaluasi yang dilakukan terhadap manajemen peningkatan kinerja guru pada SMP Negeri di Kabupaten Bandung Barat? 


\section{Kebijakan: Jurnal Ilmu Administrasi Volume 12, Nomor 1, Januari 2021 \\ E-ISSN: 2656-2820 \\ P-ISSN 1829-5762}

METODE

Secara keseluruhan, penggunaan metode dalam penelitian ini merupakan metode kualitatif atau qualitative research (naturalistic inquiry) yang menurut Bogdan dan Biklen (1982, hlm. 2) bahwa naturalistic inquiry berorientasi pada fenomena alami dan mendasar yang terjadi pada subjek penelitian. Dalam prosesnya, penelitian kualitatif ini akan mengalami perkembangan, khususnya dalam hal masalah yang diteliti, yang semuanya tergantung pada perkembangan temuan yang terjadi di lapangan (Sugiyono, 2012, hlm. 205). Sementara itu, pendekatan yang digunakan untuk mengkaji proses manajemen peningkatan kinerja guru pada SMP-SMP Negeri yang dijadikan lokasi penelitian sebagai upaya peningkatan kinerja sumberdaya manusia, dalam penelitian ini dicoba diterapkan suatu pendekatan analisis manajemen peningkatan kinerja berkelanjutan yang dikenal dengan model "siklus Deming" (Deming Cycle) atau pendekatan PDCA. Siklus Deming ini mencakup empat fase yaitu Plan, Do, Check (Study), dan Action (Andersen dalam Lodgaard dan Aasland, 2011, hlm. 3).

Adapun subjek yang ditetapkan dalam penelitian ini adalah tiga orang kepala sekolah yang meliputi kepala SMP Negeri 1 Lembang, kepala SMP Negeri 1 Padalarang, dan kepala SMP Negeri 1 Cililin beserta pengawas sekolah yang bersangkutan. Di samping itu, penelitian ini pun melibatkan sejumlah informan (key person) sebagai partisipan, yang dalam hal ini adalah guru di sekolah-sekolah tersebut dengan jumlah yang tidak ditentukan, tetapi disesuaikan dengan kebutuhan dan temuantemuan di lapangan. Hal ini didasari oleh pendapat Bungin (2007, hlm. 108) bahwa besaran key person yang digunakan sebagai informan disesuaikan dengan struktur sosial saat pengumpulan data dilakukan.

\section{PEMBAHASAN}

Secara teoretik maupun empirik, guru memiliki posisi sentral dalam proses pendidikan di sekolah, ia merupakan tokoh yang paling banyak bergaul dengan komponen lainnya di lingkungan sekolah, terutama dengan para peserta didiknya. Guru bertugas merencanakan dan melaksanakan proses pembelajaran, menilai hasil pembelajaran, melakukan bimbingan dan pelatihan, melakukan penelitian dan pengkajian, serta membuka komunikasi dengan masyarakat. Guru dituntut untuk senantiasa menggerakkan dan mendorong peserta didik benar-benar mampu menguasai bidang ilmu yang dipelajari, bukan sekedar mengikuti pelajaran. Lebih dari itu, guru pun dituntut untuk mampu membantu peserta didik memperoleh pembinaan yang sesuai dengan bakat, minat, dan kemampuan yang dimilikinya. Dengan demikian, dapat dikatakan bahwa jika ditinjau dari peran, fungsi, dan tanggung jawabnya, maka jabatan guru dapat dikategorikan sebagai jabatan profesi. Sebagai jabatan profesi, guru memiliki berbagai persyaratan standar dimana guru perlu menerapkan keahlian, kemahiran yang memenuhi standar mutu atau norma tertentu yang diperolehnya melalui pendidikan profesi sebagaimana dikemukakan Kirk dan Jones (2004, hlm. 4), "Teachers work together with the principal to ensure that expectations for student achievement are understood across classrooms and across grade levels (School Redesign Network)". Dengan demikian dapat dikatakan bahwa jabatan guru merupakan jabatan profesi yang menuntut persyaratan mengikuti pendidikan, pelatihan keterampilan dalam waktu yang cukup lama dalam bidang keahlian tertentu sebelum seseorang memiliki kewenangan khusus dalam memberikan suatu keputusan mandiri berdasarkan kode etik asosiasi yang harus dipertanggungjawabkannya. Guru sebagai seorang pendidik dituntut untuk memberikan pembelajaran secara konstan sehingga dapat mengajar berdasarkan hasil-hasil penelitian profesi terkini, mengingat dalam dunia pendidikan senantiasa terjadi perubahan mengikuti 


\section{Kebijakan: Jurnal Ilmu Administrasi Volume 12, Nomor 1, Januari 2021 \\ E-ISSN: 2656-2820 \\ P-ISSN 1829-5762}

perkembangan tuntutan masyarakat. Guru harus siap untuk membawa perubahan itu ke dalam kelas. Di sinilah kinerja guru perlu untuk senantiasa terus dikembangkan dan ditingkatkan. Oleh karena itu, dalam pelaksanaan peningkatan kinerja guru ini kepala sekolah harus mampu mengelolanya dengan baik, sementara bagi guru sendiri, tidak hanya mengandalkan program pembinaan yang diterapkan sekolah untuk meningkatkan kemampuannya, yang terpenting adalah bagaimana guru itu berusaha sendiri dalam meningkatkan kemampuan dan kinerjanya. Di sinilah Kepala Sekolah harus mampu membantu guru mengambangkan pola perilakunya, meningkatkan standar perilakunya, mampu menggunakan pelaksanaan aturan sebagai alat, serta mampu membangkitkan dan mengarahkan perilaku guru pada pencapaian tujuan.

Pengelolaan peningkatan kinerja guru di lingkungan sekolah ini tidak terlepas dari pendekatan fungsi manajemen peningkatan kinerja guru itu sendiri yang mencakup perencanaan, pengorganisasian, pelaksanaan, dan pengawasan program peningkatan kinerja secara bersinergi dan digerakan untuk mencapai apa yang telah ditetapkan dalam tujuan organisasi sekolah, maka upayaupaya peningkatan kinerja guru pada SMP-SMP Negeri di Kabupaten Bandung Barat, khususnya di SMP Negeri 1 Lembang. SMP Negeri 1 Padalarang, dan SMP Negeri 1 Cililin terus dilakukan. Meskipun upaya peningkatan kinerja guru di ketiga SMP Negeri tersebut lebih banyak dilakukan melalui pelibatan guru dalam kegiatan-kegiatan pengembangan di luar sekolah. Setidaknya Kepala Sekolah masing-masing SMP Negeri tersebut telah berusaha meningkatkan kinerja gurunya baik melalui pelibatan guru dalam kegiatan-kegiatan Musyawarah Guru Mata Pelajaran (MGMP) tingkat sekolah, kegiatan supervisi, maupun dengan menyelenggarakan kegiatan-kegiatan in-service di lingkungan sekolah.

\section{Perencanaan peningkatan kinerja guru}

Memanfaatkan sumberdaya yang ada secara lebih baik, sekolah akan dapat mengoptimalkan proses layanan belajar, hasil belajar, dan pengelolaan sekolah yang memiliki akuntabilitas terhadap lingkungannya. Sebagai paradigma strategi, Manajemen Berbasis Sekolah (MBS) dipandang Caldwell (2005, hlm. 1) sebagai:

...the systematic decentralization to the school level of authority and responsibility to make decisions on significant matters related to school operations within a centrally determined framework of goals, policies, curriculum, standards, and accountability.

Oleh karenanya, dalam organisasi sekolah model manajemen ini memerlukan seperangkat pengorganisasian yang tepat dimana sekolah sebagai suatu organisasi dikelola untuk mencapai beberapa tujuan, dan tujuan-tujuan tersebut perlu didefinisikan secara tepat serta perlu dicari cara untuk mencapainya, di sinilah perlunya fungsi perencanaan dalam pengelolaan organisasi sekolah. Begitu pula halnya dengan pengelolaan peningkatan kinerja guru dimana guru merupakan salah satu komponen penting dalam mencapai tujuan penyelenggaraan organisasi sekolah, dalam proses perencanaannya terdapat sejumlah aspek yang perlu dilaksanakan agar perencanaan tersebut dapat mengarahkan pelaksanaan kegiatan kepada apa yang menjadi keinginan atau tujuan bersama. Terkait dengan proses perencanaan tersebut, pengelolaan tenaga pendidik di SMPN 1 Lembang menjadi perhatian khusus baik dari Kepala Sekolah beserta jajaran pimpinan sekolahnya maupun dari pengawas sekolah. Demi terlaksananya kegiatan-kegiatan peningkatan kinerja guru di SMPN 1 Lembang ini, jajaran pimpinan sekolah yang terdiri atas Kepala Sekolah dan para pembantunya (PKS) merancang program-program kegiatan peningkatan kinerja guru. 


\section{Kebijakan: Jurnal Ilmu Administrasi Volume 12, Nomor 1, Januari 2021 \\ E-ISSN: 2656-2820 \\ P-ISSN 1829-5762}

Sementara itu, upaya peningkatan kinerja guru di SMP Negeri 1 Padalarang terus dilakukan, baik di dalam lingkungan sekolah maupun di luar sekolah. Bentuk-bentuk upaya peningkatan kinerja guru yang dilakukan di antaranya dengan menyelenggarakan kegiatan pelatihan in-house training (IHT) bagi para guru, pelaksanaan supervisi oleh Kepala Sekolah kepada guru secara berkelanjutan, dan partisipasi guru dalam kegiatan-kegiatan pengembangan kompetensi di luar sekolah. Upaya ini sejalan pendapat Egbo, (2011, hlm. 4) bahwa dalam membangun kapasitas guru, fokus perhatian dapat tertuju pada berbagai aspek, namun yang terpenting adalah aspek-aspek kebijakan, pelatihan/pengembangan pedagogi, pengembangan infrastuktur, dan pemberdayaan guru itu sendiri. Untuk mengetahui adanya tuntutan kebutuhan pada diri guru akan pengembangan dan peningkatan kompetensinya tersebut, berbagai masukan dari guru menjadi dasar pertimbangan Kepala Sekolah untuk merumuskan kegiatan-kegiatan peningkatan kinerja guru SMPN 1 Padalarang. Demikian pula halnya dengan pengawas sekolah sebagai pembina sekolah yang bersangkutan berusaha untuk merancang program pengawasannya dengan terlebih dahulu mengidentifikasi kebutuhan dan menganalisis kelemahan guru melalui wawancara, supervisi, dan menggali informasi dari Kepala Sekolah. Melalui upaya yang dilakukan kepala sekolah dan pengawas sekolah inilah kesiapan guru SMPN 1 Padalarang dalam menghadapi program peningkatan kinerja dapat diketahui untuk dipertimbangkan dalam perencanaan penyelenggaraannya. Pembentukan kesiapan guru terhadap program peningkatan kinerja ini sejalan dengan apa yang ditegaskan Wood, et.al. (1993, hlm. 1) bahwa kesiapan merupakan hal yang paling esensial dalam perencanaan pengembangan guru berbasis sekolah.

Demikian pula halnya dengan pengelolaan tenaga pendidik di SMPN 1 Cililin menjadi perhatian khusus baik dari Kepala Sekolah beserta jajaran pimpinan sekolahnya maupun dari pengawas sekolah. Berbagai upaya peningkatan kinerja guru di SMP Negeri 1 Cililin terus dilakukan, baik di dalam lingkungan sekolah maupun di luar sekolah. Demi terlaksananya kegiatan-kegiatan peningkatan kinerja guru di SMPN 1 Cililin ini, kepala sekolah merancang program-program kegiatan peningkatan kinerja guru SMPN 1 Cililin dengan melakukan langkah-langkah perencanaan yang mencakup aspek-aspek pembentukan kesiapan guru menghadapi kegiatan peningkatan kinerja, pembentukan iklim yang menunjang kegiatan peningkatan kinerja, penciptaan ekspektasi dan komitmen guru, serta penetapan strategi instruksional program peningkatan kinerja guru. Terkait dengan penetapan strategi instruksional dalam perogram peningkatan kinerja guru di SMPN 1 Cililin ini dirumuskan sedemikian rupa sesuai dengan tuntutan kebutuhan pengembangan kompetensi guru itu sendiri. Hal ini ditegaskan Hamalik (2000, hlm. 40-41) bahwa dalam prosedur penyusunan program peningkatan kinerja, salah satu hal yang perlu dilakukan adalah merancang strategi instruksional. upaya peningkatan kinerja guru di SMPN 1 Cililin, terdapat beberapa strategi instruksional yang dirumuskan, di antaranya program pelatihan/workshop yang lebih banyak diprioritaskan dengan rencana melibatkan guru menjadi peserta kegiatan tersebut di luar sekolah.

\section{Pelaksanaan peningkatan kinerja guru}

Pelaksanaan program-program peningkatan kinerja guru di SMPN 1 Lembang merupakan tahap implementasi dari seluruh rancangan program peningkatan kinerja guru. Tahap pelaksanaan dalam manajemen peningkatan kinerja guru, menurut Wood, et.al. (1993, hlm. 34) sebagai tahap implementasi (implementation stage) dimana nantinya para guru dan administrator akan "...move from learning in the controled setting of inservice training to adjusting, adapting, and internalizing what they have learned". 


\section{Kebijakan: Jurnal Ilmu Administrasi Volume 12, Nomor 1, Januari 2021 \\ E-ISSN: 2656-2820 \\ P-ISSN 1829-5762}

Sebelum implementasi program-program peningkatan kinerja guru di SMPN 1 Lembang ini dilakukan, sejumlah aktivitas dilakukan terlebih dahulu, yang mencakup kegiatan-kegiatan memilih dan mendesain program inservis; memilih mentor program peningkatan kinerja guru; memfasilitasi pembelajaran peserta dalam hal pengetahuan, keterampilan, sikap, gaya belajar, motivasi, implikasi dari pengkondisian, penguatan, memfasilitasi perancangan program yang nyaman (kondisi lingkungan dan event); melibatkan kegiatan-kegiatan kelompok kecil tim pembelajaran; memastikan partisipasi para administrator; serta mensosialisasikan program peningkatan kinerja guru kepada calon peserta.

Ketepatan bentuk dan strategi pembinaan yang dilaksanakan dalam program tersebut disesuaikan dengan tuntutan kebutuhan peningkatan kinerja guru itu sendiri. Berkenaan dengan perorganisasian program peningkatan kinerja guru, Wood, et.al. (1993, hlm. 20) menyebutnya sebagai tahap-tahap pelatihan (training stage) dengan salah satu kegiatan kuncinya yaitu selecting and designing an effective inservice program. Dalam program-program peningkatan kinerja guru di SMPN 1 Lembang, mentor dan supervisor program senantiasa dipilih, ditetapkan, dan difasilitasi untuk membantu membina kinerja guru di sekolah ini. Kenyataan ini sejalan dengan Blanchard dan Thacker (2013, hlm. 188) yang mengemukakan:

...one idea is to have trainers monitor trainees at some point after training to assess how they are doing and provide feedback. The trainer sits in and observes the trainee in a situation where she required to use the trained behaviour.

Berkaitan dengan bentuk desain program peningkatan kinerja guru di SMPN 1 Lembang, desain yang ditetapkan adalah berupa supervisi pembelajaran, pengarahan rutin, dan pelatihan dalam penyusunan perangkat pembelajaran, Sementara itu, pengawas sekolah lebih memprioritaskan bentukbentuk pembinaan kepada guru di SMPN 1 Lembang dalam bentuk diskusi, Forum Group Discussion, dan supervisi kelas. Dengan demikian dapat dikatakan baha pelaksanaan program peningkatan kinerja guru di SMPN 1 Lembang telah mampu memenuhi tuntutan kebutuhan akan pengembangan dan peningkatan kompetensi guru di sekolah yang bersangkutan. Namun demikian, dalam proses manajerialnya, kegiatan-kegiatan pengembangan dan peningkatan kinerja guru ini tidak dikembangkan dalam program tersendiri dengan dokumen yang disusun secara khusus sebagai suatu program peningkatan kinerja guru, sehingga setiap kegiatannya terkesan insidental dan tidak berkesinambungan dari tahun ke tahun. Sementara itu, orientasi sistem dalam peningkatan kinerja guru, program-program peningkatan kinerja guru yang dirancang untuk diterapkan di SMPN 1 Padalarang senantiasa diarahkan selaras dengan visi dan misi SMPN 1 Padalarang itu sendiri. Oleh karenanya, pemahaman guru terhadap visi dan misi sekolah ini senantiasa ditekankan kepala sekolah melalui berbagai cara, termasuk dalam kegiatan-kegiatan supervisi sebagai kegiatan pembinaan berkala.

Melalui upaya-upaya ini, orientasi dari program peningkatan kinerja guru di SMPN 1 Padalarang diharapkan dapat memberikan pemahaman kepada para guru untuk merasa bertanggung jawab dalam meningkatkan kompetensi dan kinerjanya sebagai tenaga pendidik. Upaya penyelarasan visi peningkatan kinerja guru dengan visi sekolah ini merupakan tahap persiapan sebelum peserta melaksanakan seluruh kegiatan dimana peserta diberi orientasi mengenai arah peningkatan kinerja ini yang dilanjutkan dengan pengkondisian peserta sesuai dengan strategi atau metode yang akan diterapkan (Hamalik, 2000, hlm. 78-79). Selain itu, dalam program peningkatan kinerja guru, proses pembimbingan peserta melalui penerapan metode apapun, hal terpenting yang harus diutamakan menurut Wood, et.al (1993, hlm. 37) adalah menyadari apa yang dilakukan tetap konsisten dengan harapan dan mengidentifikasi cara-cara khusus untuk meningkatkan praktek profesional mereka, hal 


\section{Kebijakan: Jurnal Ilmu Administrasi Volume 12, Nomor 1, Januari 2021 E-ISSN: 2656-2820 \\ P-ISSN 1829-5762}

ini akan memotivasi mencapai keberhasilan, dan hal ini pula lah yang senantiasa perlu dilakukan oleh supervisor. Demikian pula halnya yang dilakukan oleh Kepala SMPN 1 Padalarang dalam membina kinerja para gurunya. Melalui kegiatan-kegiatan supervisi yang dilakukan kepala sekolah, setiap guru senantiasa dibimbing dan diarahkan agar terus meningkatkan kompetensi dalam pelaksanaan tugasnya di sekolah. Di sini, tampak bahwa kepala sekolah senantiasa memberikan bimbingan dan arahan kepada guru untuk menjalankan tugasnya melalui proses supervisi akademik dengan memeriksa kelengkapan perangkat pembelajaran, mengamati proses pembelajaran, serta memberikan evaluasi sekaligus memperhatikan upaya pemenuhan kebutuhan proses pembelajaran.

Pelaksanaan program peningkatan kinerja guru di SMPN 1 Padalarang telah mampu memenuhi tuntutan kebutuhan akan pengembangan dan peningkatan kompetensi guru di sekolah yang bersangkutan. Namun demikian, seperti halnya yang terjadi di SMPN 1 Lembang, dalam proses manajerialnya, kegiatan-kegiatan pengembangan dan peningkatan kinerja guru ini tidak dikembangkan dalam program tersendiri dengan dokumen yang disusun secara khusus sebagai suatu program peningkatan kinerja guru, sehingga setiap kegiatannya terkesan insidental dan tidak berkesinambungan dari tahun ke tahun. Berkenaan dengan pelaksanaan program-program peningkatan kinerja guru tersebut, terdapat sejumlah aktivitas yang dilakukan, yaitu memberikan orientasi peningkatan kinerja guru; kegiatan tatap muka antara pelatih/mentor dengan peserta; pembimbingan peserta; pemberian sumberdaya; pengkondisian peserta sesuai dengan strategi yang diterapkan; mendorong peserta berbagi pengalaman; serta memastikan pengembangan rencana penerapan. Tahap pelaksanaan dalam manajemen peningkatan kinerja guru ini sejalan dengan pendapat Wood, et.al. (1993, hlm. 34) yakni sebagai tăhap implementasi (implementation stage) dimana nantinya para guru dan administrator akan .....move from learning in the controled setting of inservice training to adjusting, adapting, and internalizing what they have learned".

Setiap upaya peningkatan kinerja guru baik yang dilakukan di dalam lingkungan sekolah maupun di luar lingkungan sekolah sudah semestinya memperlihatkan kejelasan orientasinya bagi para guru yang menjadi sasaran peningkatan kinerja itu sendiri. Kejelasan orientasi ini akan sangat mempengaruhi keberhasilan dari proses peningkatan kinerja guru itu sendiri. Orientasi sistem yang diterapkan dalam suatu program peningkatan kinerja guru akan sangat menentukan strategi atau metode yang diterapkan dalam program tersebut. Berkenaan dengan orientasi sistem dalam peningkatan kinerja guru ini, program-program peningkatan kinerja guru yang dirancang untuk diterapkan di SMPN 1 Cililin senantiasa diarahkan selaras dengan visi dan misi SMPN 1 Cililin itu sendiri. Sementara itu, dalam sistem pengajaran terpadu pada program-program peningkatan kinerja guru, pelatih/mentor berperan dalam membimbing kelompok-kelompok kerja peserta dalam mendiskusikan suatu permasalahan atau materi yang sedang dibahas. Demikian pula halnya dengan peran mentor dalam program-program peningkatan kinerja guru di SMPN 1 Cililin yang diselenggarakan di lingkungan sekolah dimana pengembangan pengetahuan dan wawasan guru, terutama dalam hal pelaksanaan pembelajaran, dilakukan melalui kegiatan-in-house training (IHT). Oleh karenanya, kegiatan tatap muka anrara guru yang menjadi peserta dalam program peningkatan kinerja dalam bentuk sharing baik pada program pelatihan maupun pada kegiatan-kegiatan forum MGMP dengan pelatih/mentor cenderung membicarakan hal-hal mengenai wawasan pengajaran. Proses manajerialnya, kegiatan-kegiatan pengembangan dan peningkatan kinerja guru di SMPN 1 Cililin ini tidak dikembangkan dalam program tersendiri dengan dokumen yang disusun secara khusus sebagai suatu program peningkatan kinerja guru, sehingga setiap kegiatannya terkesan insidental dan tidak berkesinambungan dari tahun ke tahun. 


\section{Kebijakan: Jurnal Ilmu Administrasi Volume 12, Nomor 1, Januari 2021 \\ E-ISSN: 2656-2820 \\ P-ISSN 1829-5762}

\section{Pelaksanaan dan evaluasi peningkatan kinerja guru}

Fungsi yang terakhir dalam proses manajemen adalah fungsi pengendalian (controlling) dimana termasuk di dalamnya kegiatan-kegiatan pengawasan, membandingkan, dan mengoreksi kinerja. Di sinilah monitoring dan evaluasi merupakan bagian terpenting dalam proses manajemen peningkatan kinerja guru. Berkenaan dengan hal ini, Conor (2006) mengemukakan bahwa keberhasilan dalam mencapai tujuan, setengahnya ditentukan oleh rencana yang telah ditetapkan dan setengahnya adalah bagian dari fungsi pengawasan. Setiap pengetahuan dan pengalaman yang diperoleh guru dari program peningkatan kinerja pada umumnya selalu diupayakan untuk terus diterapkan. upaya-upaya implementasi hasil yang diperoleh dari program-program peningkatan kinerja guru SMPN 1 Lembang dalam pelaksanaan pembelajaran terus dilakukan dibawah pengawasan kepala sekolah melalui program-program supervisinya. pengawas sekolah yang berperan pula sebagai mediator antara sekolah dengan pemerintah berusaha untuk menunjukkan langsung program-program yang telah mengalami keberhasilan tersebut sebagai bentuk program peningkatan kinerja guru yang memadai. Cara seperti ini merupakan salah satu bentuk cara pembaharuan sebagaimana dikemukakan Hall dan Loucks (Wood, et.al., 1993, hlm. 46) mengemukakan tiga model dukungan, yaitu memperjelas kembali (refinement), integrasi (integration), dan pembaharuan (renewal).

Di SMPN 1 Padalarang, setiap pengetahuan dan pengalaman yang diperoleh guru dari program peningkatan kinerja pada umumnya selalu diupayakan untuk terus diterapkan. upaya-upaya implementasi hasil yang diperoleh dari program-program peningkatan kinerja guru SMPN 1 Padalarang dalam pelaksanaan pembelajaran terus dilakukan dibawah pengawasan kepala sekolah melalui program-program supervisinya. $\mathrm{Di}$ sini, pengawas sekolah yang berperan pula sebagai mediator antara sekolah dengan pemerintah berusaha untuk menunjukkan langsung program-program yang telah mengalami keberhasilan tersebut sebagai bentuk program peningkatan kinerja guru yang memadai. Sementara itu, berkenaan dengan pengawasan dan eyaluasi program-program peningkatan kinerja guru di SMPN 1 Cililin, terdapat sejumlah aktivitas yang dilakukan, yaitu mengkonfirmasi penggunaan program dan praktek baru; memastikan bahwa perubahan diimplementasikan secara berkelanjutan; serta mendukung penggunaannya pada tingkat yang lebih tinggi. Itulah sebabnya pengawas sekolah sebagai mediator antara sekolah dengan pemerintah berusaha untuk menunjukkan langsung program-program yang telah mengalami keberhasilan tersebut sebagai bentuk program peningkatan kinerja guru yang memadai sebagai suatu bentuk pembaharuan (Hall dan Loucks, dalam Wood, et.al., 1993, hlm. 46).

\section{SIMPULAN}

Program peningkatan kinerja guru di SMPN 1 Lembang, SMPN 1 Paalarang, dan SMPN 1 Cililin KBB pada dasarnya di ketiga sekolah tersebut menunjukkan adanya persamaan upaya yang dilakukan, yakni tuntutan kebutuhan kinerja guru telah diidentifikasi baik oleh kepala sekolah maupun pengawas yang berarti bahwa tuntuan kebutuhan kinerja guru ini telah diketahui dan menjadi dasar perlunya upaya peningkatan kinerja guru di sekolah. Namun, masih terdapat beberapa aspek yang tidak dilaksanakan, yakni kurangnya atau bahkan tidak adanya upaya pelibatan guru dalam perecanaan dan tidak dilakukannya perumusan prosedur program beserta kriteria pengukurannya, sehingga peningkatan kinerja guru di ketiga sekolah ini tidak terukur secara jelas.

Terkait dengan proses manajerial dalam pelaksanaannya, peningkatan kinerja guru di ketiga SMP ini tidak dikembangkan dalam program tersendiri dengan dokumen yang disusun secara khusus 


\section{Kebijakan: Jurnal Ilmu Administrasi Volume 12, Nomor 1, Januari 2021 \\ E-ISSN: 2656-2820 \\ P-ISSN 1829-5762}

sebagai suatu program peningkatan kinerja guru, sehingga setiap kegiatannya terkesan insidental dan tidak berkesinambungan dari tahun ke tahun. Dalam hal pengawasan dan evaluasi peningkatan kinerja guru di ketiga SMP Negeri di Kabupaten Bandung Barat ini, upaya-upaya mendorong guru untuk mengimplementasikan hasil keterlibatannya dalam program peningkatan kinerja sudah dilaksanakan meskipun pada umumnya baru sebatas dituangkan dalam perangkat pembelajaran, sedangkan implementasinya dalam proses pembelajaran kurang terkontrol secara berkelanjutan.

\section{DAFTAR PUSTAKA}

Blanchard, P. N. and Thacker, J. W. (2013) Effective Training: Systems, Strategies, and Practices. New Jersey: Pearson Education, Inc.

Bogdan, R.C. and Biklen, S.K. (1982) Qualitative Research to Education: An Introduction to Theory and Methode. Boston: Alyn \& Bacon, Inc.

Bungin, B. (2007) Penelitian Kualitatif: Komunikasi, Ekonomi, Kebijakan Publik, dan Ilmu Sosial Lainnya. Jakarta: Prenada Media Group.

Caldwell, B. J. (2005). School Based Management. International Academy of Education Brusel Belgium.

Conor, O., Iselin, E., and Sharma, D. (2006) The Relative of Element of Internal Control on Audithor's Evaluation of Control. Pacific Accounting Review. Vol. 18 (2).

Egbo, B. (2011) Teacher Capacity Building and Effective Teaching And Learning:A Seamless Connection. Proceedings of the 2011 International Conference on Teaching, Learning and Change (c) International Association for Teaching and Learning (IATEL).

Hamalik, O. (2000) Pengembangan Sumber Daya Manusia: Manajemen Pelatihan Ketenagakerjaan Pendekatan Terpadu. Jakarta: Bumi Aksara.

Kirk, D. J. \& Jones, T. L. (2004) Effective Schools. Assessment Report. Pearson Education Inc.

Lodgaard, E. and Aasland, K. E. (2011) An Examination of The Application of Plan-Do-Check-Act Cycle in Product Development. Paper for International Conference on Engineering Design (ICED11). 15 - 18 August 2011, Technical University of Denmark.

Sianturi, R. (2018) Manajemen Peningkatan Kinerja Guru Berbasis Sekolah (Studi Kualitatif pada SMPN 1 Lembang, SMPN 1 Padalarang, dan SMPN 1 Cililin Kabupaten Bandung Barat). Disertasi SPS UPI (tidak diterbitkan)

Sugiyono. (2012) Metode Penelitian Kuantitatif, Kualitatif, dan R \& D. Bandung: Alfabeta.

Wood, F. et.al. (1993) How to Organized a School-Based Staff Development Program. AlexandriaVirginia: Association for Supervision and Curriculum Development. 